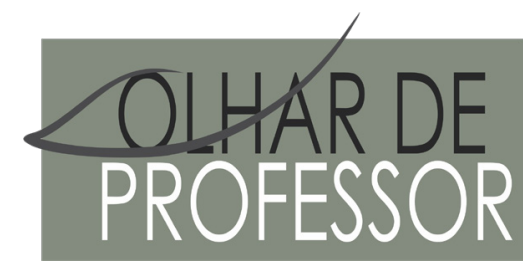

DOI: 10.5212/OLHARPROFR.v.23.2020.15577.209209225596.0528

\title{
EXPERIENCES OF UNIVERSITY EDUCATION IN VIRTUALITY IN THE PUBLIC AND PRIVATE CONTEXT IN COLOMBIA
}

\author{
CAMPO ELÍAS FLÓREZ PABÓN ${ }^{*}$ \\ JENNY PATRICIA ACEVEDO-RINCÓN*
}

\section{INTRODUCTION}

Colombian basic, middle and higher education is governed by the Colombian Ministry of National Education $\left(\mathrm{MEN}^{1}\right)$. Higher Education Institutions are entities that have official recognition to be providers of the public service of higher education in the Colombian territory, whose legal nature is characterized by being of a public or private character. The former have general guardianship control as a public establishment and the latter enjoy constitutional and legal prerogatives that, even from the same jurisprudence, have had significant development in terms of scope, to the point of pointing out that these are organizations that belong to none of the branches of public power or private universities (2020).

The current health crisis reveals the digital gap that was immersed in the Colombian educational system. According to the Ministry of Science and Technology -MINTIC ${ }^{2}$, the digital gap is recognized as the socioeconomic difference between those communities that have access to ICTs and those that do not, in addition to the differences between groups according to their ability to use ICTs effectively, due to the different levels of literacy and technological capacity (MINTIC, 2019).

Furthermore, this context implies that the digital gap is not closed in Colombia, as evidenced by the report on the digital gap monitoring project presented by MINTIC, but that until now the data on the digital divide is being configured to take action, idea that would be developed in this annuity. Despite this reality, the decision made worldwide was to continue with online classes regardless of the socioeconomic reality of the inhabitants in any region, and Colombia was no exception. Next, two experiences are described, developed in Colombian public and private universities, which are constituted in virtual training actions that incorporate methodological innovations in the development of classrooms in the human and exact sciences. From this reality, the experiences of the University of Pamplona and the University of the North in public and private virtuality are presented, respectively.

\section{EXPERIENCES OF TEACHING OF HUMANITIES IN THE PUBLIC SECTOR.}

The University of Pamplona was founded by the presbyter José Rafael Faría Bermúdez, according to the biographical sketch of Flórez-Pabón (2019, P. 19), without having a preponderant religious link

\footnotetext{
* Philosophical Doctor (Unicamp, Brazil). Professor at Universidad de Pamplona (Unipamplona). Norte de Santander, Colombia. E-mail: ceflorez@unipamplona.edu.co. ORCID: https://orcid.org/0000-0003-0443-8432.

${ }^{* *}$ Educational Doctor (Unicamp, Brazil). Professor at Universidad del Norte (Uninorte). Atlántico, Colombia. E-mail: pjacevedo@uninorte.edu.co. ORCID: https://orcid.org/0000-0003-3872-5130

${ }^{1}$ For its initials in Spanish.

${ }^{2}$ For its initials in Spanish.
} 
other than the occupation that its founder had. Entrepreneurship that makes it the first public university in the state since the late sixties. In its current historical time, in the midst of the crisis caused by the coronavirus pandemic, it can be said that it has students from all over the country because of their areas of influence of the Distance Education Centers (CREAD), as well as a population of all social strata for its affordable prices due to the place where it is located, which makes the lifestyle inexpensive. This profile outlines the university context of the public institution, an idea that allows us to focus on the experience of teachers at a public university in Colombia amid the pandemic.

The teachers of public Higher Education Institutions (HEIs) in Colombia, before the process imposed by the national government, had thought, somehow, that virtual education is a reality that would have to come in the mediate future, and not immediately as it is in the case of the health crisis. It was always considered that there would be time to prepare for this work, although this was not the case. It is fondly remembered those days that will no longer return for any teacher. Those timid steps that were taken years ago today are true marathon competitions in favor of a virtual education, without, at the end of the goal, we think that there is a golden medal rather than having experience in a virtual pedagogical process that took another speed to assume.

Specifically, in the case of teachers at the University of Pamplona, a remote exercise was proposed, since what is done today is far from what is understood by virtual education, (following the guidelines of the Colombian MEN), in the good sense of the word, because, with this experience, already a vision of this reality in a sense that is not adequate is given. The University assumed this reality from one week to the next, without too much preparation or instructions. The first thing that appeared was a format where it was asked to write down the week the course was going, to the courses managed by the teachers, to see if it coincided with the syllabus or programmatic contents exposed in a face-to-face phase of the semester. In addition, in a column of the format was asked to list virtual teaching strategies, without properly discriminating the subject and nature of the course. To this, we must add that the teacher's own resources were taken up, which, later, shone in virtues as free license tools for teaching, without reflecting any logistical difficulties on the part of the teacher, namely equipment, connectivity, software, preparation, etc.

Likewise, it must be said that, among public universities, the University of Pamplona has experience in some virtual subjects, supported by its own tools such as Academusoft 4.0 software for both educational management and online education. The problem is that this institutional Moodle tool was suggested after teachers had already developed their strategies in the human sciences in the teaching of philosophy. In this way, some opted for Google Classroom, under the modality of a personal account and not Google for Education, others for Microsoft Teams, among other possibilities that could be known as WhatsApp or email.

However, Google Classroom, in its personal account version, does not directly integrate interactivity and meetings for free in the accounts but are a series of institutional G-suites that must be processed by the institution, both in the academic order As in the economic licenses with Google company, and with what there was began this work. To this we can add the support for free licenses from the Avaya platform for education, which together with the Microsoft Teams are also a valid tool for virtual education managed by the institution. On the other hand, with the observation that the Avaya manuals are not clear because they are in English this caused some teachers to become discouraged in the application of these subsidies to virtual public education. Thus, it becomes a necessary duty to take note of all these shortcomings for the exercise of virtual education in the public university in the mediate and immediate future.

\section{EXPERIENCES OF TEACHING OF THE GEOMETRY IN THE PRIVATE CONTEXT.}

The Universidad del Norte has been working since 1966 in the city of Barranquilla. It is currently located at kilometer 5 of the highway to Puerto Colombia (Atlántico-Colombia), is a private higher education institution subject to inspection and surveillance by Law 1740 of 2014 and Law 30 of 1992 of the MEN (UNINORTE, 2020). It has High-Quality institutional accreditation and has recently been considered one of the ten best universities in Colombia for its comprehensiveness and academic excellence. 
As a result of the pandemic, from the rectory of the Universidad del Norte (Colombia), its staff (teaching and administrative) were asked to do work at home from March 17, 2020 to start in the remote mode from March 30, 2020. Two weeks in which the professors of the Universidad del Norte had the opportunity to rethink the syllabus corresponding to each subject, now with the university's own digital alternatives and many others that were found along the way.

In this sense, the university has the Blackboard platform that offers different alternatives for content publication, communication between students and professors (discussion forums, messages or external mail), consultation tools in the virtual library, search for help and grades, and the Blackboard Collaborate Ultra interface, where virtual meetings are scheduled and developed. The latter has been of great advantage when making the synchronous connection with students because it allows the viewing of documents, screen sharing with students for interaction during class. In addition, these classes are recorded, downloaded and stored in the University drive, which has a greater storage capacity, in order to, through the link, allow access to students who failed to do so synchronously to class.

Therefore, one of the challenges of virtuality presupposes the paradigm shift in the teaching and learning of mathematics, since it is the first thing that is thought in the face of ancient practices that involve board and marker and the replication of formulas. Thus, the Geometry course was designed so that Graphic Design students could make compressions on the classic Euclidean Geometry and its development through the transition between 2D and 3D. Hence, in accordance with the above, the new virtual environment implied the development of other ways to involve the student in their learning. For this, constructions were used with a dynamic geometry software called GeoGebra that has privileged the use of constructions of classic forms, such as the characterization of new Applets (applications built within the resource) which allow us to see geometric objects. In this way, on some occasions, the classes involve video tutorials for the identification of the resource and primary constructions of known elements, these are elaborated with the Screen Recorder Launcher and, also, the students participate in the asynchronous explanations of the workshops carried out by them in GeoGebra showing video tutorials of its constructions through the same tool.

Synchronous classes are distributed in two workspaces for a total of 3 hours. In the first one class, in general, new concepts are developed through an illustrated explanation with Applets, which takes a maximum of 40 minutes synchronously, understanding that students must do independent work for the rest of the time, without depending on a connection synchronous. The second one is used to develop other concepts, under the group work structure of the Blackboard Collaborate Ultra platform which allows us to collaboratively develop tasks and deliver them during the development of the class, so the duration of this class is the two hours, knowing that the work is in connection with small groups and that it depends on the rhythm of work of its members. This course has two students with a neurodevelopmental disorder and one with a specific learning disorder, who have the support of the Resource Center for Student Success (CREE), University Wellbeing and the Uninorte Inclusive committee for teachers and students, which implies close communication with these agencies to make the pertinent curricular adaptations to achieve the learning results. Therefore, it is important to highlight that this way of working has allowed us to propose a flexible and universal learning experience that benefits all students, offering various forms of presentation and representation of information, multiple opportunities for expression and action, and multiple forms of commitment to learning, in accordance with what is proposed in the Universal Learning Design (DUA) framework. Finally, all this work has also been supported through the use of the WhatsApp groups tool, whose means of communication reinforces what has been said by email and, in the announcements section of the platform, for those who do not have immediate access to the internet, but yes to a data plan.

\section{CONCLUSIONS}

The socio-economic, topographic and cultural reality of the country does not conform to the strategies promoted by previous governments. Despite the conditions of the declared state of emergency, the Ministry of National Education, together with the national government, has made proposals that 
adapt, in a certain way, to the possibilities of each of the Colombian universities (public and private). Currently, strategies have been implemented in the universities that, although without prior planning, have responded to the needs of the educational sector with possibilities of connection. On the other hand, it did not happen in the same way with the public university, since both the private and public universities have low-income populations (1 and 2), who mostly have scholarships from their localities or from national programs. Virtuality accentuates the lack of democratization of education, widening the digital gap within its participants which, ultimately, further widens the digital gap, an example of this, people from the rural sector and vulnerable populations were excluded from this proposal of "virtualization "of education. Among the difficulties faced by this sudden transition to virtuality, it is had that the ergonomic working conditions of students and teachers are not adequate for the development of long working hours that they must assume, in order to successfully finish the current semester. This leads to the segregation of the poor, but also of those who do not have the technological access to education, of those who have only one computer with several children studying, of those who do not have an adequate infrastructure for work, be they parents, children, students or teachers. Added to this, the lack of teaching (and student) experience has meant that this modality implies more time in the preparation of classes and the achievement of tasks.

Likewise, a new learning space implies commitments that start from the self-regulation of both work and student responsibilities, in addition to representing a change in the very structure of the development of the classes in the face of aspects of curricular, pedagogical and even time flexibility access to each one of the activities. In this way and in accordance with what is proposed in Acevedo-Rincón and Flórez Pabón (2019), a virtuality proposal leads to rethinking the pedagogical task and the way in which we evaluate learning in students since evaluations of only algorithm replication (in mathematics) make no sense in any of the models. This has been the opportunity given to us to rethink ourselves as educators and to project another education. Also, to contemplate other models of decentralized teaching, personalized according to the learning objectives. However, today more than ever, the importance of the teaching role is evident, because, although the physical presence is not felt, there is a need for constant accompaniment for the development of adequate competences, as well as to advance in the knowledge of the contents of the course. Likewise, it is evident that the experience of an educational practice cannot be replaced by a video tutorial or an endless number of tasks assigned to "occupy" the students, but rather that each of the class proposals allows the student to advance to the extent that the development of competencies requires it.

\section{REFERENCES}

ACEVEDO-RINCÓN, J. P.; FLÓREZ-PABÓN, C. E. TelEduc: A virtual learning environment for teaching and learning at the University of Campinas, Brazil. Journal of Physics: Conference Series. 2019, 1161. 012023. 10.1088/1742-6596/1161/1/012023. https://doi.org/10.1088/17426596/1161/1/012023.

FLÓREZ-PABÓN, C. E. Faría, marxismo y comunismo. Cuadernos de filosofía latinoamericana. Bogotá: USTA. 2019, vol. 40 Núm. 121. https://doi.org/10.15332/25005375.5468.

MINISTERIO DE EDUCACIÓN NACIONAL - MEN. Instituciones de educación superior, 2020, Online: https://www.mineducacion.gov.co/1759/w3-article-231240.html?_noredirect=1. Consultado el consultado 19-abril-2020.

MINISTERIO DE CIENCIA Y TECNOLOGÍA -MINTIC. Brecha digital. Bogotá, 2020.. Online: https://www.mintic.gov.co/portal/inicio/5467:Brecha-Digital. Consultado 20-abril-2020.

UNIVERSIDAD DEL NORTE. Nuestra historia. Barranquilla, 2020. Online: https://www.uninorte. edu.co. Consultado: 14-mayo-2020. 